\title{
The Effect of Recast on Iranian EFL Learners' Writing Achievement
}

\author{
Samira Zabihi \\ Department of Translation Studies, Fars Sciences and Research Branch \\ Islamic Azad University, Fars, Iran
}

Received: 22-06-2013

Accepted: 31-07-2013

Published: 01-11-2013

doi:10.7575/aiac.ijalel.v.2n.6p.28

URL: http://dx.doi.org/10.7575/aiac.ijalel.v.2n.6p.28

\begin{abstract}
Developing English language learners' writing skill has always been a concern in the ELT profession.This study presents the findings of an investigation on the effect of recast as a major type of indirect corrective feedback on English language learners' writing skill. For the purpose of this study, a total number of 20 advanced language learners enrolled in writing classes were randomly selected from a language institute in Shiraz, Iran. The treatment involved assigning some topics to learners to write about. The compositions were collected and corrected after the fifth composition by the teacher using recast strategy as the major corrective feedback method. The data collected during this 5 -session treatment based the pre-test of this study. Then the learners' original compositions and the corrected versions were returned to them. The degree of accuracy and also the number and types of corrected errors observed in three compositions assigned later, which served as the post-test of this study, determined the degree of effectiveness of this type of indirect error correction technique on the development of writing skill. The results revealed that recast had a positive impact on decreasing errors. The comparison of the pre-test and post-test scores shows that recasts significantly assisted in increasing accuracy of writing.
\end{abstract}

Keywords: Recast, corrective feedback, writing

\section{Introduction}

Feedback on error has been a traditional pedagogical practice in the EFL/ESL classrooms. Corrective feedback allows second language learners to make progress in their ability to use the target language appropriately. By providing learners with both positive and negative evidence, corrective feedback is considered as a useful technique believed to facilitate L2 development (Long, 1996). Positive evidence provides the learners with the correct and target-like structure or what is acceptable in L2. Negative evidence, however, shows the learners what is unacceptable in L2. Corrective feedback is defined as a teacher's move to draw a learner's attention to the grammatical accuracy of the utterance s/he has produced (Sheen, 2007). Previous research has addressed the influence of different types of corrective feedback in language classrooms (Macky, Gass, \& McDonough, 2000; Lyster, 2004; Loewen, 2004; Sheen, 2004). One widely used implicit negative feedback technique in second language acquisition is recast- the teacher's correct restatement of a learner's incorrect sentence.

Recast was initially identified in first language acquisition. Bohannon et al. (1996, as cited in Sheen (2006) define recast as a correction technique "that expands, deletes, permutes, or otherwise changes the platform while maintaining overlap in meaning" (p. 434). To Ellis (2003), "recast involves rephrasing an utterance" by changing one of its components while meaning is kept unchanged (p. 168). Recast can thus be seen as the reformulation of learners' incorrect utterances. Mackey (2006) defines recast as a target-like model aimed at correcting students' wrong sentences. In this sense, recast is considered as positive evidence (information about which forms are grammatical in the target language) for learners than negative one. The following example shows how recast works.

Student: She is a good cooker

Teacher: A good cook. Is She? (Recast)

Student: Yes she is a good cook (Modified output)

Although having a similar nature, recast has a variety of forms. Gass (2003) categorizes recast into "partial recast", "full recast," "recast in response to single error," and "recast in response to multiple errors". Partial recast is the modification of the inaccurate part of an utterance (Sheen, 2006) or according to Lyster (1998), it is a recast which is carried out through reduction or "a reduction of the learner's utterance with added stress for emphasis" (p. 271). Also, Lyster (1998) differentiats "isolated" from "incorporated" recast. While isolated recast refers to recast without making any modification in meaning (through addition or deletion), incorporated recast concerns adding the corrected reformulation to the meaning of utterance. Mackey and Philp (1998) drew a distinction between "intensive" recast and "complex and simple" recasts. While intensive recast emphasizes a single linguistic item, complex recast is concerned with multiple linguistic items. Moreover, Sheen (2006) distinguishes "conversational" from "didactic" recast; the former deals with meaning, the latter with form. 
Recast is seen a corrective negative feedback that signifies deviation from its correct target-language form without explicit explanation, which gives the learner the opportunity to see and contrast the two forms and identify an error. Unlike direct error corrections, recasts are contextualized, that is they allow the learner to focus on an erroneous item in a context, not in isolation. Such contextualization can lead to a more effective acquisition of language forms (Degteva, 2011).

Studies on the effects of recast on oral and written output of EFL learners are numerous due to the important role of corrective feedback and recast on escalating the accuracy of language production. As Long (2007) claims, there is growing support from research proving that recasts facilitate language development. Studies by Doughty and Varela (1998), Ishida (2004), Choi (2000), Ortega and Long (1997) favored the use of recast in SLA instructions.

The present study attempts to investigate the effect of corrective feedback in the form of recasts on the development of L2 learners' writing ability, focusing on learners' linguistic errors.

\section{Literature Review}

Error correction literature has mainly focused on whether teachers need to correct students' writing errors, and if yes, and how this should be carried out. Writing teachers' perceptions as well as students' beliefs and attitudes regarding error feedback have also been the subject of ample research. Lee (2004), for example, studied error correction practices in the Hong Kong secondary writing classroom from the viewpoints of both teachers and students. There were three main data collection sources: (1) a teacher survey including a questionnaire, followed by interviews, (2) a teacher error correction task, and (3) a student survey comprising a questionnaire and follow-up interviews. The results indicated that both teachers and students favored comprehensive error feedback, the teachers did not extensively use error feedback strategies, and that some of the teacher corrections of student errors were inaccurate. The study also revealed that the students were highly dependent on teachers' error correction, and that the teachers were not much mindful of the lasting importance of error feedback.

Hamouda (2011) compared students and teachers' preferences and approaches towards correction of writing errors Saudi EFL context. Findings were indicative of the positive attitudes of both teachers and students towards written error correction. The study also showed that although teachers and students think similarly in terms of the significance of error correction and the error types, there are some differences regarding error correction techniques. For example, students prefer overall correction, but most teachers do not. The results revealed that students prefer to be corrected by their teacher rather than themselves or their peers.

Literature also indicates that providing feedback to students' writings has always been a controversial and even inconclusive issue. Trusscott (1999) argued that not only is error correction of little benefit to learners, but also harmful and thus should not be done in EFL writing classrooms. On the other hand, Ferris (2002) sees error correction as an important factor in improving learners' writing ability. Some other studies (Cohen, 1987; Ferris \& Roberts, 2001) also highlight the importance of accuracy and hence error correction in students' writings and the students' willingness to receive feedback on their errors.

Ferris and Roberts (2001) contend that the issue as to whether error correction causes an improvement in students' writing accuracy and their overall writing ability remains unresolved. Chandler (2003) found out that having received error correction, students were asked to take the corrections into account were thus less likely to repeat the same errors in their writings.

Another controversial issue in the literature is whether error corrections should be done directly or indirectly. Abedi, Latifi, and Moinzadeh (2010) compared the effect of direct vs. indirect error correction on the improvement of Iranian pre-intermediate EFL learners' writing ability. Results showed that there is a significant difference in the scores obtained from the direct feedback group and indirect feedback group in the post test. That is, using coded feedback was shown to exert a positive effect on the writing ability improvement of the learners compared to direct ones. It was observed that those learners who received indirect feedback on their writing through error detection using codes, showed greater improvement in their writing. In fact, the subjects performed better on writing test through exposure to the coded feedback, and not the direct correction. Erel and Bullut (2007), too, have found out that the indirect coded feedback group made fewer mistakes than the direct feedback group.

Previous research has shown that recast is the most commonly used type of error correction technique in classrooms (Sharwood, 1994; Ellis, 2003; Sheen, 2006). In a comparative study, Maftoon, Shirazi, and Daftarifard (2011) compared the effect of recast and self-correction in classrooms through a writing task. To this end, two groups of students received two methods of recast and self-correction were to determine if the methods make any difference in the their writing accuracy of the learners in their use of past tense. Results showed although students improve after treatment, the two methods do not differ. However, self-correction technique was proved to be more effective than recast and recast did not develop students' accuracy.

With this in mind and given the dearth of research on the effectiveness of error correction in general and recast in particular on the Iranian EFL leaners' writing achievement, the present study endeavors to fill in the gap in the literature by providing more insight into the effect of recast on Iranian EFL learners' writing performance.

\section{Theoretical Background}

Some researchers support the idea that recasts are effective in SLA. For example, Long \& Robbinson (as cited in Nicholas, Lightbown, \& Spada, 2001) indicate that the recast shows learners how the utterances they produce differ 
from the target language utterances. Other researchers argue that recasts are not highly beneficial in SLA. For example, Lyster (1998, as cited in Nicholas, Lightbown, \& Spada, 2001) argues that recasts are ambiguous and may be seen by the learner as confirmation of the meaning rather than feedback on form. Most of the research conducted on the role of recasts in SLA supports the idea that recasting plays a helpful and facilitative role in SLA. The degree of benefit received depends on such factors as the way the recast is done, the students' learning level, the context in which the recast is offered, the kind of errors that need recasting, etc.

There are two explanations regarding the beneficial role recast plays in SLA. Each is founded on a major theoretical framework in SLA. The first is concerned with what is called the 'noticing hypotheses'. According to this hypothesis, language learners need to first be aware of the linguistic items in the input in order to be able to acquire them (Schmidt, 1990, as cited in Nicholas, Lightbown, \& Spada, 2001). As recast includes immediate reaction to a learner's wrong utterance, it then draws the learner's attention to certain linguistic structures when the learner compares the ones in the recast to those (s)he has produced. The second theoretical framework stems from Universal Grammar Model. In this model, Schwartz (as cited in Nicholas, Lightbown, \& Spada, 2001) shows that the effectiveness of the recasts does not lie in its role as 'negative evidence'. Instead, it simply provides 'positive evidence'. As such, learners are not consciously aware of the fact that recasts are aimed to be corrective, and in this case the benefit of the recast lies in the fact that the learners has been provided with proper positive evidence.

\subsection{Research Questions}

This study aims at providing answer to the following research questions:

1. Do recasts encourage EFL learners to attend to linguistic forms in writing?

2. Do recasts decrease the number of linguistic errors and increase accuracy in writing?

As such, the following two research hypotheses are formed:

H1: Recasts do not encourage EFL learners to attend to linguistic forms in writing.

$\mathrm{H} 2$ : Recasts do not have any effect on decreasing the number of linguistic errors and increasing accuracy in writing.

\section{Method}

\subsection{Participants}

Recasts is most effective in settings where learners know that the recast is a reaction to the accuracy of the form, not the content, of their utterances (Nicholas, Lightbown, and Spada, 2001; Dasse-Askildson, 2008). Therefore, recasts should be addressed to learners of quite a high level of proficiency, if they are to be effective. This conclusion defined the choice of the participants for the study.

The participants of this study comprised of 20 advanced Iranian EFL learners enrolled in a writing class in a language institute in Shiraz, Iran. This class was randomly selected among six writing classes in this institute. The participants had enrolled in this class to improve their writing skill to be prepared to take part in the IELTS exam. They had all undergone a placement test to make sure they are in advanced level of English to be able to take part in an IELTS class. The participants were both males and females ranging from 20 to 32 years of age and had varying degrees of exposure to language instruction (from 7 to 10 years).

It was explained to the participants that a research study was conducted which concerned their writing, but no detail about feedback or recasts was provided to prevent the participants from being influenced by the objectives of the study.

\subsection{Procedures}

The experiment consisted of assigning ten topic-based writings to the participants of the study. The essays were on topics that are more common in the writing section of the IELTS test such as immigration, education, technology, language learning experience, traffic, children's bad behavior, etc. The students had to write a 250 -word essay in forty minutes. During sessions one to five, the participants' writing papers were collected and corrected using recast technique. The data collected this way served as the pre-test of this study. The participants' essays were analyzed and the linguistic errors were detected and corrected using recast. Their original writings and the corrected versions were then returned to the them. After a two-session interval, three more topics (different from those of the pre-test) were introduced to them during sessions eight to ten, which served as the post-test of this study. Each class session lasted one hour and forty-five minutes. After the post-test, the last three compositions were analyzed. Then the pre- and post-test analyses were compared with each other. The purpose was to examine the degree these participants could benefit from recast strategy, the extent to which this strategy had recovered linguistic errors observed in the first five compositions as well as the degree of improved accuracy in the participants' writings.

\subsection{Data analysis}

The data for the study consisted of eight written texts from each participant (160 texts in total), the first five serving as data for the pre-test (to identify the frequent linguistic error types prior to the treatment, the next three serving as the post-test (to examine the effectiveness of the strategy under investigation). Each text was analyzed for errors and the observed linguistic errors were codified into twenty categories as follows:

1) WW - wrong word (e.g view meaning look)

2) P - preposition (using a wrong preposition)

3) WS - wrong structure (omitting a subject) 

4) $\mathrm{WO}$ - word order
5) Cond - conditional clause
6) Interr - wrong formation of interrogative sentence
7) Copulab - copula "be"
8) TF - wrong tense formation
9) Quant - quantifier
10) Demonp - demonstrative pronoun
11) Determ - determiner
12) Indp - indefinite pronoun
13) A - article
14) Inf - infinitive
15) Gerund
16) $\mathrm{S} / \mathrm{Pl}$ - singular or plural
17) Poss - possessive
18) T - tense (incorrect choice of tense)
19) Mod - modal verb
20) $\mathrm{Sp}$ - spelling
21)

The students' errors in their writings were identified based on the twenty categories indicated above. Each sample was examined and analyzed, errors were underlined and a corresponding code for each error was placed in the margin. At the end of each sample, a total number of errors was indicated. For the purpose of scoring reliability, a peer was asked to analyze the students' errors using the twenty categories. Any discrepancy in scoring was later discussed.

\section{Results and Discussion}

The first research question of the study sought whether recasts encourage learners to attend to linguistic forms in their writing. The qualitative analysis of the written texts consisted of examining the changes or omissions of each type of errors observed in the pre-test from the post-test. The purpose of the analysis was to discover a change in the incorrect use of linguistics forms into correct target-language forms based on the treatment under investigation. The following table provides the error production percentage of each category of errors produced by each participant during the pretest and post-test.

Table 1. Error production percentage in pre-test and post-test

\begin{tabular}{llll}
\hline Participants (P) & Error Categories & $\begin{array}{l}\text { Pre-test } \\
\text { (Percentage) }\end{array}$ & $\begin{array}{l}\text { Post-test } \\
\text { (Percentage) }\end{array}$ \\
\hline P1 & WW & 27 & 9 \\
\hline P2 & P & 34 & 12 \\
\hline P3 & WS & 47 & 13 \\
\hline P4 & WO & 39 & 11 \\
\hline P5 & Cond & 41 & 16 \\
\hline P6 & Interr & 39 & 14 \\
\hline P7 & Copulab & 21 & 7 \\
\hline P8 & TF & 27 & 9 \\
\hline P9 & Quant & 33 & 13 \\
\hline P10 & Demonp & 29 & 11 \\
\hline P11 & Determ & 42 & 16 \\
\hline P12 & Indep & 32 & 18 \\
\hline P13 & A & 45 & 22 \\
\hline P14 & Inf & 41 & 19 \\
\hline P15 & Gerund & 30 & 12 \\
\hline P16 & S/P1 & 26 & 6 \\
\hline P17 & Poss & 28 & 6 \\
\hline P18 & T & 43 & 22 \\
\hline P19 & Mod & 38 & 14 \\
\hline P20 & Sp & 31 & 13 \\
\hline
\end{tabular}

As can be seen in Table 1, students committed a variety of errors in their writing. It can be seen that the most widelycommitted errors in the pre-test include wrong structure (47\%), followed by article (45\%), tense (43\%), and the use of determiners ( $42 \%)$. In the post-test, however, these errors reduced to $13 \%, 22 \%$, and $16 \%$ respectively. Such finding is in line with that found by Eret and Bulut (2007) who found out that learners made different types of errors in their writings. Such errors included punctuation, spelling, word form, prepositions, articles, pronoun, etc. In their study, it was also found out that there was a steady decrease in the number of errors the students made during the semester. As an example, the frequency of making preposition errors fell from $59 \%$ to $43 \%$. 
The fewer number of errors the participants in the present study made in the post-test could be attributed to the effect of recast the learners received during the pre-test. Results illustrated in Table 1 show considerable decrease in the frequency of errors made by the learners. The error level drops significantly after the texts written during pre-test phase were examined by the researcher, returned to the participants and reviewed by them. The recast provided to the learners in their written texts could help them avoid some errors in their subsequent writing. The reason is that written feedback in the form of recasts increased attention and awareness of the participants. So it is suggested that the decrease in the use of erroneous forms after the treatment was caused by the participants' attention to and awareness of the recasted versions of erroneous linguistic forms. This led to a steady increase in the participants' accuracy in their writing. As such, the first research hypothesis of the study, which stated recasts do not encourage EFL learners to attend to linguistic forms in writing, is rejected, as it was proved that students made fewer errors in their post-test writing, which is an indication of their attention to linguistic forms in their writing.

Research carried out on error correction in writing classes, too, demonstrates that students who receive error feedback from teachers become more accurate over time (Ferris \& Roberts, 2001). Previous research (Leki, 1991; Ferris \& Roberts, 2001; Chandler, 2003; Erel and Bulut, 2007; Sivaji, 2012) support the notion that students tend to receive feedback on the errors they make, and believe in its usefulness in improving their writing skill. In an investigation of the effectiveness of written recasts, Ayoun (2001) concluded that learners who received recasts outperformed those who received explicit grammar instruction. As such, the researcher concludes that recasting is the most effective form of feedback.

As mentioned above, learners made various errors in their pre-test writings. The following table illustrates some of the examples of such errors.

Table 2. Examples of errors produced by learners during the pre-test phase (beforerecast)

\begin{tabular}{lll}
\hline Error Categories & Examples & Justification \\
\hline Indefinite pronoun & $\begin{array}{l}\text { She didn't care about her and } \\
\text { never told something about her life. }\end{array}$ & Erroneous form \\
\hline Modals & $\begin{array}{l}\text { Everyone can do it and I will able to do. } \\
\text { You are small yet and it will be able to be } \\
\text { dangerous enough for you. }\end{array}$ & Erroneous forms \\
\hline Wrong structures & $\begin{array}{l}\text { There was fresh, calmly. } \\
\text { There was fun. } \\
\text { There is so sunny in the room. } \\
\text { But here is not very cold. } \\
\text { In spring there is not much dirtily. } \\
\text { In summer there is not stuffy }\end{array}$ & Erroneous forms \\
& $\begin{array}{l}\text { Nobody ask a question. } \\
\text { There were many room in that building. }\end{array}$ & \\
\hline $\boldsymbol{S} / \boldsymbol{P l}$ & $\begin{array}{l}\text { The ancestors who live in the past talked } \\
\text { about it. }\end{array}$ & Erroneous form \\
\hline $\boldsymbol{T F}$ & $\begin{array}{l}\text { She was born at German. } \\
\text { She strongly discussed to the manager. }\end{array}$ & Erroneous forms \\
\hline $\boldsymbol{P}$ & $\begin{array}{l}\text { Recieve, Beleive, Beautifull, Tasety, } \\
\text { Wether. }\end{array}$ & Erroneous form \\
\hline $\boldsymbol{S p}$ & & \\
\hline & &
\end{tabular}

Table 2 above demonstrates some of the errors students made in their pre-test, that is before receiving recasts on their writing. As can be seen, learners made different types of errors in their writing, including indefinite pronouns, modals, preposition, spelling, etc. This requires careful attention paid by teachers such errors made by learners in their writing.

The second research question of the study sought if recasts decrease the number of linguistic errors made by learners and thus increase accuracy in writing. Table 3 below shows variation coefficients of errors produced by all participants during the pre-test and post-test.

Table 3. Coefficients of variation in the pre-test and post-test

\begin{tabular}{lll}
\hline Participants (P) & Pre-test & Post-test \\
\hline P1 & $\mathrm{CV}=0.28$ & $\mathrm{CV}=0.04$ \\
\hline P2 & $\mathrm{CV}=0.32$ & $\mathrm{CV}=0.04$ \\
\hline P3 & $\mathrm{CV}=0.31$ & $\mathrm{CV}=0.03$ \\
\hline P4 & $\mathrm{CV}=0.39$ & $\mathrm{CV}=0.06$ \\
\hline P5 & $\mathrm{CV}=0.38$ & $\mathrm{CV}=0.04$ \\
\hline P6 & $\mathrm{CV}=0.41$ & $\mathrm{CV}=0.06$ \\
\hline P7 & $\mathrm{CV}=0.36$ & $\mathrm{CV}=0.03$ \\
\hline
\end{tabular}




\begin{tabular}{lll}
\hline P8 & $\mathrm{CV}=0.40$ & $\mathrm{CV}=0.08$ \\
\hline P9 & $\mathrm{CV}=0.29$ & $\mathrm{CV}=0.05$ \\
\hline P10 & $\mathrm{CV}=0.34$ & $\mathrm{CV}=0.06$ \\
\hline P11 & $\mathrm{CV}=0.37$ & $\mathrm{CV}=0.03$ \\
\hline P12 & $\mathrm{CV}=0.40$ & $\mathrm{CV}=0.07$ \\
\hline P13 & $\mathrm{CV}=0.36$ & $\mathrm{CV}=0.09$ \\
\hline P14 & $\mathrm{CV}=0.29$ & $\mathrm{CV}=0.06$ \\
\hline P15 & $\mathrm{CV}=0.32$ & $\mathrm{CV}=0.04$ \\
\hline P16 & $\mathrm{CV}=0.42$ & $\mathrm{CV}=0.08$ \\
\hline P17 & $\mathrm{CV}=0.35$ & $\mathrm{CV}=0.05$ \\
\hline P18 & $\mathrm{CV}=0.34$ & $\mathrm{CV}=0.04$ \\
\hline P19 & $\mathrm{CV}=0.37$ & $\mathrm{CV}=0.06$ \\
\hline P20 & $\mathrm{CV}=0.28$ & $\mathrm{CV}=0.04$ \\
\hline
\end{tabular}

As shown in Table 3, the degree of errors that the participants had produced during the pre-test has significantly decreased during the post-test. Put it simply, a noticeable decrease can be observed in the degree of errors made by the participants of the study in the pre-test and those of the post-test. This indicates that the participants benefited from the recasts they were provided, and that their writing accuracy increased. As such, the second research hypothesis of the study, which stated that recasts do not have any effect on decreasing the number of linguistic errors and increasing accuracy in writing, is rejected. Previous research (e.g. Erel and Bulut, 2007; Sivaji, 2012), too, supported the findings of the present study by showing that providing learners with error correction feedback made their writings more accurate. The participants in Erel and Bulut's (2007) made fewer errors during the semester as a result of the feedback they received on their errors. The researchers finally concluded that error correction helps students improve their accuracy in writing regardless of the type of correction. Chandler (2003), too, found out that students' accuracy in writing increased as they were exposed to feedback on their errors.

\section{Conclusion}

According to Richards and Renandya (2008) writing is the most difficult skill for L2 learners to master. Such difficulty lies not only in generating and organizing ideas, but also in translating these ideas into a readable text. They state that the skills involved in writing are highly complex; L2 writers have to pay attention to higher level skills of planning and organizing as well as lower level skills of spelling, punctuation, word choice, and so on. The difficulty becomes even more pronounced if their language proficiency is weak. Therefore, writing play a key role in classroom studies of second language acquisition. The important point in writing, however, concerns errors and whether they should be corrected or tolerated. It is unanimously acknowledge by most writing teachers that teacher corrective feedback is an indispensable part of any writing course and student seek teacher feedback on their errors (Ferris \& Roberts, 2001). Among different kinds of correction techniques used, recast seems to be the most common use one (Ellis, 2003; Sheen, 2004, 2006). The present study sought the effectiveness of recast on Iranian EFL learners' writing achievement. Findings suggested that the recasts provided to the learners assisted them in their writing by reducing the number of errors they made in their writings. As such, recasts proved to be effective in increasing learners' awareness of their linguistic inaccuracies and thus improved their writing performance.

Different researchers have investigated the effect of error correction on learners' writing ability. According to Ferris (2003), error correction is seen by teachers as fundamental to developing learners' writing ability. The present study, too, supported the notion that recast, as a form of error correction, could contribute to learners' writing improvement.

It can also be argued that the reason of learners' making fewer mistakes in their post-test writings in the present study could be attributed to the effort made by the researcher to provide recast for the learners. This would make learners reflect more on their written texts and be aware of their linguistic problems, which is similar to consciousness raising task (Ellis, 2003), and this would lead to more encouragement and higher degree of independence on the part of learners.

Therefore, it can be concluded that error correction in general and recast in particular can be seen as a valuable tool in the hand of language teachers for teaching grammatical and linguistic forms implicitly, so that learners would be able to reach a high level of improvement in writing. This would alleviate the weaknesses associated with direct error correction, which, as Krashen (2003) put it, would impede the learners' language development

\section{References}

Abedi, R., Latifi, M., \& Moinzadeh, A. (2010). The effect of error correction vs. error detection on Iranian preintermediate EFL learners' writing achievement. English Language Teaching, 3(4), 168-174.

Ayoun, D. (2001). The role of negative and positive feedback in the second language acquisition of the "passe compose" and the "imparfait." Modern Language Journal, 85(2), 226-243. 
Chandler, J. (2003). The efficiency of various kinds of error feedback for improvement in the accuracy and fluency of L2 student writing. Journal of Second Language Writing, 12, 267- 296.

Choi, M.Y. (2000). Effects of recasts on irregular past tense verb morphology in Web-chat. Unpublished master's thesis, University of Hawai'i, Honolulu. Available from Wiley online library http://onlinelibrary.wiley.com/doi/10.1111/j.1540-4781.2010.01143.x/pdf

Cohen, A. (1987). Student Processing of Feedback on Their Compositions. In: A.L. Weden, \& J. Rubin (Eds.), Learner Strategies in Language Learning (pp. 57-69). Englewood Cliffs, NJ: Prentice-Hall.

Dasse-Askildson, V. (2008). How learners' affective variables impact their perception of recasts in the acquisition of grammatical gender in L2 French. Arizona Working Papers on SLA and Teaching, 15, 1-35.

Degteva, O. (2011). Impact of recasts on the accuracy in EFL learners' writing. Norderstedt: Germany.

Doughty, C., Varela, E. (1998). Communicative focus on form. In C. Doughty \& J. Williams (Eds.), Focus on form in classroom second language acquisition (pp. 114-138). Cambridge: Cambridge University Press. Retrieved May 13, 2011, from Questia database: htpp://www.questia.com

Ellis, R. (2003). Task-based language learning and teaching. Oxford: OUP.

Errel, O. S., \& Bulut, D. (2007). Error treatment in L2 writing: A comparative study of direct and indirect coded feedback in Turkish EFL context. Sosyal Bilimler Enstitüsü Dergisi Sayl, 22, 1, 397-415.

Ferris, D.R. (2002).Treatment of Error in Second Language Student Writing. Michigan: University of Michigan Press.

Ferris, D. R. (2003). Response to student writing: Implications for second language students. Mahwah, NJ: Lawrence Erlbaum Associates.

Ferris, D. R., \& Roberts, B. (2001). Error feedback in L2 writing classes: How explicit does it need to be? Journal of Second Language Writing, 10(3), 161-184.

Gass, S. M. (2003). Input and Interaction. In C. Doughty, and M. Long (Eds.), The handbook of second language acquisition (pp. 224-255). New York: Blackwell.

Hamouda, A. (2011). A study of students and teachers' preferences and attitudes towards correction of classroom written errors in Saudi EFL context. English Language Teaching, 4(3), 128-141.

Ishida, M. (2004). Effects of Recasts on the Acquisition of the Aspectual Form -te $i$-(ru) by Learners of Japanese as a Foreign Language. Language Learning, 54, 311-394. doi: 10.1111/j.1467-9922.2004.00257.x

Krashen, S. (2003). Explorations in Language Acquisition and Use: The Taipei Lectures. Portsmouth, NH: Heinemann.

Lee, I. (2004). Error correction in L2 secondary writing classrooms: The case of Hong Kong. Journal of Second Language Writing, 13(4), 285-312.

Leki, I. (1991). The preferences of ESL students for error correction in college-level writing classes. Foreign Language Annals, 24(3), 203-218.

Loewen, S. (2004). Uptake in incidental focus on form in meaning-focused ESL lessons. Language Learning, 54, 153188.

Long, M. (1996). The role of the linguistic environment in second language acquisition. In W. C. Ritchie \& T. K. Bhatia (Eds.), Handbook of Second Language Acquisition (pp. 413-468). San Diego, CA: Academic Press.

Long, M. H. (2007). Problems in SLA. Mahwah, NJ: Lawrence Erlbaum Associates.

Lyster, R. (1998). Recasts, repetition, and ambiguity in L2 classroom discourse. Studies in Second Language Acquisition, 20, 51-81.

Lyster, R. (2004). Different effects of prompts and recasts in form-focused instruction. Studies in Second Language Acquisition, 26, 399-432.

Mackey, A. (2006). Feedback, noticing and instructed second language learning. AppliedLinguistics, 27(3), 405-430.

Mackey, A., S. Gass, and K. McDonough. (2000). How do learners perceive interaction feedback? Studies in Second Language Acquisition, 22, 471-498.

Mackey, A., and Philp, J. (1998). Conversational interaction and second language development: Recasts, responses, and red herrings? Modern Language Journal, 82, 338-356.

Maftoon, P., Shirazi, M. A., and Daftarifard, P. (2011). The effect of recast vs. self-correction on writing accuracy: The role of awareness. Broad Research in Artificial Intelligence and Neuroscience, 2(1), 17-28.

Nicholas, H., Lightbown, P., \& Spada, N. (2001). Recasts as Feedback to Language Learners. Language Learning, 51(4), 719-758.

Ortega, L., Long, M. H. (1997). The effects of models and recasts on the acquisition of object topicalization and adverb placement in L2 Spanish. Spanish Applied Linguistics, I, 65-86. 
Richards, Jack C., \& Renandya, Willy A. (2002). Methodology in Language Teaching: an Anthology of Current Practice. Cambridge: Cambridge University Press.

Sharwood, M. (1993). Second language learning: Theoretical foundations. London: Longman.

Sheen, Y. (2004). Corrective feedback and learner uptake in communicative classrooms across instructional settings. Language Teaching Research, 8(3), 263-300.

Sheen, Y. (2006). Exploring the relationship between characteristics of recasts and learner uptake. Language Teaching Research, 10 (4), 361-392.

Sheen, Y. (2007). The effects of corrective feedback, language aptitude, and learner attitudes on the acquisition of English articles. In A. Mackey (Eds.), Conversational Interaction in Second Language Acquisition: A Collection of Empirical Studies (pp. 301-322). Oxford: Oxford University Press.

Sivaji, K. (2012). The effect of direct and indirect error correction feedback on the grammatical accuracy of ESL writing of undergraduates. Journal of Humanities and Social Sciences, 7(8), 91-113.

Truscott, J. (1999). Noticing in Second Language acquisition: A critical review. Second Language Research, 14(2), 103-135. 